$1989,38,2$

УДК 541.14

R. JÄ̈LAID, T. PEHK, T. KANGER, M. LOPP, U. LILLE

\title{
CHIRAL SULFOXIDES FROM DITHIOKETALES OF BICYCLO[3.2.0]HEPT-2-EN-6-ONE AND ITS EPOXIDE
}

R. JAALAID, T. PEHK, T. KANGER, M. LOPP, O. LILLE. KIRAALSED SULFOKSIIDID BITSUKLO[3.2.0]HEPT-2-EEN-6-OONI JA TEMA EPOKSIIDI DITIOKETAALIDEST

Р. ЯАЛАИД. Т. ПЕХК, Т. КАНГЕР, М. ЛОПП, Ю. ЛИЛЛЕ. ХИРАЛЬНЫЕ СУЛЬФОКСИДЫ ИЗ ДИТИОКЕТАЛЕИ [3.2.0]ГЕПТ-2-ЕН-6-ОНА И ЕГО ЭПОКСИДА

In the course of studies of optical resolution of the known prostaglandin intermediate, bicyclo[3.2.0] hept-2-en-6-one, thioketales (1) and (2) were oxidized in the modified Sharpless oxidation conditions [ $\left.{ }^{1}\right]$ $\left(t\right.$ - $\mathrm{BuO}_{2} \mathrm{H}: \mathrm{Ti} / \mathrm{O} i$-Pr/4 ${ }_{4}(-)$-DET:substrate $\left.2: 1: 4: 5\right)$ and the following three diastereomers $(3 \mathrm{a}-\mathrm{c}$ and $4 \mathrm{a}-\mathrm{c}$, respectively) were obtained after separation on silica gel $\left(\mathrm{CCL}_{4}\right.$ :acetone 10:1-6:1).

The structures of these diastereomers were determined by ${ }^{1} \mathrm{H}$ and ${ }^{13} \mathrm{C}$ NMR spectra by various $2 \mathrm{D}$ methods.

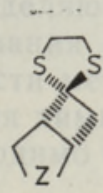

$(1,2)$

$(1) ;(3 a-c)$
$(2) ;(4 a-c)$

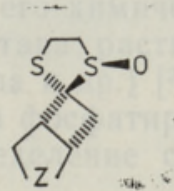

$(3 a, 4 a)$

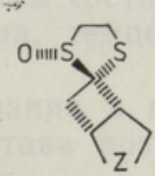

$(3 b, 4 b)$

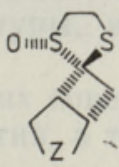

$(3 c, 4 c)$

Judging by the molecular modelling the formation of the fourth diastereomer was hindered for steric reasons.

NMR data and optical activity of the diastereomers obtained

\begin{tabular}{l|l|l|l|l|c|c}
\hline & ${ }^{1} \mathrm{H}_{5}$ & ${ }^{1} \mathrm{H}_{\text {7exo }}$ & ${ }^{1} \mathrm{H}_{\text {7endo }}$ & ${ }^{13} \mathrm{C}_{5}$ & ${ }^{13} \mathrm{C}_{7}$ & $\begin{array}{c}{[\alpha]_{D}\left(t,{ }^{\circ} \mathrm{C} ; C, \%\right.} \\
\left.\mathrm{CHCl}_{3}, 11\right)\end{array}$ \\
\hline (1) & 3.33 & 3.08 & 3.32 & 52.5 & 47.3 & - \\
$(2)$ & 3.36 & 2.89 & 2.80 & 55.9 & 41.0 & - \\
$(3 \mathrm{a})$ & 3.83 & 2.89 & 2.05 & 37.8 & 38.4 & $+3.7(26 ; 6)$ \\
(3b) & 2.93 & 3.32 & 2.03 & 43.0 & 34.4 & $+17(27 ; 5)$ \\
(3c) & 3.25 & 2.64 & 2.93 & 48.5 & 34.9 & $+33(27 ; 5)$ \\
(4a) & 3.78 & 2.63 & 2.37 & 41.4 & 32.8 & 0 \\
(4b) & 3.11 & 3.29 & 2.48 & 46.1 & 27.8 & $+53(14 ; 4)$ \\
(4c) & 3.21 & 2.55 & 3.23 & 53.8 & 28.6 & $+3.3(26 ; 1.5)$
\end{tabular}


The results obtained show that the oxidation in the system under study proceeds with moderate regioselectivity and high stereoselectivity in respect to one diastereomer formed. This requires further studies to explain the steric background of stereoselectivity.

\section{REFERENCES}

1. Bortolini, O. a. o. Asymmetric oxidation of 1,3-dithiolanes. A route to the optical resolution of carbonyl compounds // Tetrahedron Lett., 1986, 27, N 51, 62576260 .

Academy of Sciences of the Estonian SSR,

Received

Institute of Chemistry

Nov. 28,1988 